\title{
The Contribution Of Kiai Munawwar Adnan Kholil Gresik On Islamic Education
}

\author{
Muhammad Anas Ma'arif, ${ }^{1}$ Nur Silva Nabila ${ }^{2}$ \\ ${ }^{1}$ Institut Institut Pesantren KH Abdul Chalim Mojokerto, Indonesia \\ ${ }^{2}$ Universitas Islam Negeri Sunan Ampel Surabaya, Indonesia \\ 1'anasdt16@gmail.com, ${ }^{2}$ nursilvanabila24@gmail.com
}

\begin{abstract}
Pesantren as an indigenous culture can create unique traditions and creations. The creation of a pesantren because of the persistence of its founder, the Kiai. The pesantren will remain an educational reference if the pesantren system well managed. Narrative research conducted by Kiai Munawwar because of his expertise in managing and creating science education. It still has not been much written about the Kiai Munawwar. This research uses philosophical historical by narrating the characters, works, biography, and analyze the contribution to Islamic education. This research aims to describe, analyze the gait and contribution of Kiai Munawwar Kholil Gresik to Islamics education, especially pesantren and the development of students' careers. The results of the research: 1) Kiai Munawwar made a maximum contribution in Gresik through formal, non-formal education and life skills education for his students. 2) Works written used as a pesantren education curriculum. 3) Life skill education means of (khidmah) in the pesantren. 4) Pesantren education aims to form ulama and generous tycoons. 5) Educational methods by telling history. The recommended future can be researching Kiai Munawwar's from various perspectives or indepth biographical research.
\end{abstract}

Keywords: Kiai Munawwar, Islamics Education, Contribution

\begin{abstract}
Abstrak
Pesantren sebagai indegeneous culture mampu menciptakan tradisi-tradisi dan karya-karya yang unik. Terciptanya suatu pesantren adalah disebabkan oleh kegigihan pendirinya yaitu Kiai. Pesantren akan tetap menjadi sebuah referensi pendidikan apabila sistem dan manajemen pesantren dikelola dengan baik. Pentingnya melakukan penelitian naratif dari Kiai Munawwar adalah karena kepakaranya dalam mengelola pendidikan dan menciptakan karya-karya yang banyak diberbagai bidang ilmu. Hal ini belum banyak yang menulis tentang kiai Munawwar. Penelitian ini menggunakan penelitian historisfilosofis dengan menarasikan tokoh, karya dan biografinya serta menganalisis kontribusinya dalam pendidikan Islam. Tujuan dari penelitian ini adalah untuk mendeskripsikan dan menganalisis kiprah dan kontribusi Kiai Munawwar Kholil Gresik terhadap pendidikan Islam khususnya pesantren dan pengembangan karir santri. Penelitian ini menghasilkan: 1) Kiai Munawwar memberikan kontribusi secara maksimal di Gresik melalui pendidikan formal, non formal dan pendidikan life skill bagi santri-santrinya. 2) karya-karya yang telah ditulis mampu dijadikan sebagai kurikulum pendidikan pesantren 3) pendidikan life skill sebagai sarana khidmah di pesantren. 4) Tujuan pendidikan pesantren membentuk uluma dan konglomerat yang dermawan 5) metode pendidikan dengan bercerita (kisah) Rekomendasi: Penelitian selanjutnya bisa
\end{abstract}


meneliti karya-karya Kiai Munawwar dari berbagai perspektif atau penelitian biografi secara mendalam.

Kata Kunci: Kiai Munawwar, Pendidikan Islam, Kontribusi

\section{Introduction}

Gresik is a city in East Java with the nickname Gresik santri city (Gresik Kota santri). ${ }^{1}$ Branding is not without reason because of the many historic graves called Wali Songo guardian of nine. ${ }^{2}$ Among them, there are the tombs of Sunan Maulana Malik Ibrahim, and Sunan Giri. ${ }^{3}$ It is also mentioned from history that the first pesantren was established in Gresik commanded by Sunan Maulana Malik Ibrahim. ${ }^{4}$

The history is attached to the nickname Gresik as a city of students. And this is also proven by the number of Islamic boarding schools that continue the tradition of Islamic boarding schools. From the data collected by the Gresik government in 2016, there were 65 boarding schools. ${ }^{5}$ Some pesantren are more than 200 years old, namely Qomaruddin Islamic Boarding School in 1775 and Islamic Boarding School Maskumambang 1896.6-7 With many Islamic Boarding School in Gresik and historical evidence such as old graves, it is inseparable from the role of ulama, and Kiai who struggle to preserve tradition. ${ }^{8}$

The struggle of a Kiai should be enshrined by writers who can remember and emulate the history and struggle. As with some of the historical struggles of Kiai Bashori

\footnotetext{
${ }^{1}$ Kompasiana, 'Julukan Gresik Kota Santri', Kompasiana, 2018, https://www.kompasiana.com/hana5301/5d8a391f0d823073b6406072/julukan-gresik-kota-santri.

${ }^{2}$ Nora Faridatin, 'Kota Gresik Sebagai Kota Santri "Implikasi Sebagai City Branding", Thaqafiyyat: Jurnal Bahasa, Peradaban Dan Informasi Islam 17, no. 1 (2 June 2016): 106-21, http://202.0.92.5/adab/thaqafiyyat/article/view/1083; Charisma Amanda, "Religi" Sebagai Pendekatan Desain Untuk Fasilitas Wisata Di Kota Gresik', Jurnal Sains Dan Seni ITS 4, no. 2 (2016).

${ }^{3}$ Agus Sunyoto, Atlas Wali Songo: buku pertama yang mengungkap Wali Songo sebagai fakta sejarah (Kerjasama Pustaka IIMaN, Trans Pustaka, dan LTN PBNU, 2016).

${ }^{4}$ Ramayulis, Sejarah Pendidikan Islam, Napaktilas Perubahan Konsep, Filsafat dan Metodelogi Pendidikan Islam dari Era Nabi Saw sampai Ulama Nusantara (Jakarta: Kalam Mulia, 2012); Zamakhsyari Dhofier, Tradisi pesantren: studi pandangan hidup kyai dan visinya mengenai masa depan Indonesia, Cet. 8 rev (Jakarta: LP3ES, 2011); M. Ridlwan Nasir and M. Adib Abdushomad, Mencari Tipologi Format Pendidikan Ideal: Pondok Pesantren Di Tengah Arus Perubahan, Cet. 1 (Yogyakarta: Pustaka Pelajar, 2005).

${ }^{5 ‘}$ COunter_webgresik', 2016, https://www.powr.io/hit-counter/u/f0c2dd77_1501400614.

${ }^{6}$ Mochamā Chairudin, 'Strategi Pengembangan Pondok Pesantren Qomaruddin Gresik', Jurnal Ilmu Pendidikan Islam 15, no. 1 (16 June 2017): 73-88, http://ejournal.kopertais4.or.id/pantura/index.php/jipi/article/view/3378.

${ }^{7}$ Joko Sayono, 'Perkembangan Pesantren Di Jawa Timur', Bahasa Dan Seni, 2005.

${ }^{8}$ Mohammad Takdir, 'Kontribusi Kiai Kholil Bangkalan Dalam Mengembangkan Tasawuf Nusantara', 'Anil Islam: Jurnal Kebudayaan Dan Ilmu Keislaman 9, no. 2 (31 December 2016): 268-99, http://jurnal.instika.ac.id/index.php/AnilIslam/article/view/18; Wasid and Mahsun, 'Kiai Abdul Hamid Pasuruan Dan Kontribusinya Untuk Moderasi Islam', Al Fikrah 1, no. 1 (2018): 71-81.
}

Tribakti: Jurnal Pemikiran Keislaman

Volume 31, Nomor 2, Juli 2020 
Alwi, written by Abdul Malik Karim. ${ }^{9}$ According to Karim, Kiai Bashori struggled to develop pesantren by writing (written works). The struggle of Kiai Maskyur Cirebon by opposing colonialism and teaching education to the surrounding community. ${ }^{10} \mathrm{Wasid}$ also wrote about the contribution of KH Hamid Pasuruan in the struggle for religion and pesantren with Sufism. ${ }^{11}$ Abdul Kadir ${ }^{12}$ writes about the concept of human thought written by Kiai Asrori Surabaya, a murshid of the Tareeqa Qodiriyah Naqsabandiyah. The modernization of education carried out by KH Zarkasyi and his efforts in Islamic moderation. ${ }^{13}$

From various historical evidence and writings to be a role model later, the writer was intrigued to write about 'the contribution of KH Munawwar Kholil Gresik to Islamic education'. The author considers this research important because KH Munawwar Gresik is a Kiai who has many works, Kiai whom experts in the field of Sufism, Kiai who struggle for the community by establishing formal education, and informal and Kiai who have scholarly scholars who connected to Rasulallah Saw. ${ }^{14}$ Because of the importance of imitating the struggle of Kiai by writing down the struggle and its contribution so that later it will not only be a story from the mouth. The author found little evidence of writing about Kiai Munawwar Gresik like wrote about leadership in developing the Islamic Boarding School Daruttaqwa. ${ }^{15}$ Muhammad Anas Ma'arif in 2019 wrote short biography and educational concepts.

The results of previous research on Kiai Munawwar studied by Ernawati about the type of leadership. Kiai Munawwar leading the pesantren and educational institutions. It was divided into three types of leadership namely charismatic, traditional

\footnotetext{
${ }^{9}$ Abdul Malik Karim Amrullah, 'Kontribusi Karya Tulis Kiai Basori Alwi Terhadap Pengembangan Wawasan Keagamaan Masyarakat', Ulul Albab Jurnal Studi Islam 13, no. 1 (17 September 2013): 35-48, https://doi.org/10.18860/ua.v0i0.2381.

${ }^{10}$ Aah Syafaah, 'Peran Dan Perjuangan Kiai Masykur Di Desa Karangsari Weru Cirebon (18351961)', Holistik 1, no. 2 (1 December 2016): 215-27, https://doi.org/10.24235/holistik.v1i2.1124.

${ }^{11}$ Wasid and Mahsun, 'Kiai Abdul Hamid Pasuruan Dan Kontribusinya Untuk Moderasi Islam'.

${ }^{12}$ Abdul Kadir Riyadi, 'The Concept of Man in Ahmad Asrori's Anthropology of Tasawuf', Journal of Indonesian Islam 11, no. 1 (9 July 2017): 223-246-246, https://doi.org/10.15642/JIIS.2017.11.1.223246.

${ }^{13}$ Hamid Fahmy Zarkasyi, 'Appraising the Moderation Indonesian Muslims with Special Reference to Muhammadiyah and Nahdlatul Ulama', Addin 12, no. 1 (2018): 1-30, https:/www.neliti.com/publications/272038/appraising-the-moderation-indonesian-muslims-withspecial-reference-to-muhammadi; Mahrus As'ad, 'Tajdīd Al-Tarbīyah al-Islāmīyah 'inda al-Shaykh alḤājj Imam Zarkasyi’, Studia Islamika 22, no. 2 (31 August 2015): 333-68, https://doi.org/10.15408/sdi.v22i2.1922.

${ }^{14}$ Ernawati, 'Kepemimpinan Kh. Munawar Adnan Kholil Dalam Mengembangkan Pondok Pesantren Daruttaqwa Suci Gresik Tahun 1987-2012', Avatara 3, no. 2 (21 May 2015), https://jurnalmahasiswa.unesa.ac.id/index.php/avatara/article/view/11496.
} 
and rational leadership. ${ }^{15}$ Muhammad Anas and Husnur Rofiq also examined the concept of Kiai Munawaar's education with dhikr which resulted that students and teachers should have a pure inner bond so that the light of the heart inside the heart was clean so that good character would appear. ${ }^{16}$ Dhikr makes the mind and heart clearer so students and teachers should always dhikr either in learning or outside of learning. Indeed, not many people researched Kiai Munawaar but in fact, stated that Kiai Munawwar became a reference for Gresik and surrounding communities in terms of worship and gain knowledge.

As a comparison with previous research on the work of the Kiai in the world of education is the result of Kadariska's research on Islamic education in Sukabumi initiated by Kiai Sanusi. ${ }^{17}$ The Kiai should surely fight for society through Islamics education. Like Kiai Basori Alwi Malang, ${ }^{18}$ who fought for Islamics education with the characteristic of writing. While the Sidogiri Islamic Boarding School further develops its students in entrepreneurship. ${ }^{19}$ Like Kiai Kholil Bangkalan who fought for the surrounding community with Islamic education. ${ }^{20}$

Thus, history can be written well and there is no difficulty in finding historical evidence because the period of the Indonesian struggle did not write much about the progress of pesantren, ${ }^{21}$ and there are many informants who still know the struggle and Kiai Munawwar then, the writer will try to describe and analyze the contribution of KH Munawwar to Islamic education in Gresik.

15 Ernawati, 'Kepemimpinan Kh. Munawar Adnan Kholil Dalam Mengembangkan Pondok Pesantren Daruttaqwa Suci Gresik Tahun 1987-2012'.

${ }^{16}$ Maarif and Rofiq, 'Dzikir Dan Fikir Sebagai Konsep Pendidikan Karakter'.

17 Siti Kadariska, 'Perjuangan K.H. Ahmad Sanusi dalam Memajukan Pendidikan Islam di Sukabumi Tahun 1922-1950' (diploma, UIN Sunan Gunung Djati Bandung, 2018), http://digilib.uinsgd.ac.id/13700/.

18 Amrullah, 'Kontribusi Karya Tulis Kiai Basori Alwi Terhadap Pengembangan Wawasan Keagamaan Masyarakat'.

19 Chusnul Chotimah, 'Pendidikan Kewirausahaan Di Pondok Pesantren Sidogiri Pasuruan', Inferensi: Jurnal Penelitian Sosial Keagamaan 8, no. 1 (2014): 114-36, https://doi.org/10.18326/infsl3.v8i1.114-136.

20 Aah Syafaah, 'Menelusuri Jejak Dan Kiprah Kiai Kholil Al-Bangkalani', Jurnal Tamaddun: Jurnal Sejarah Dan Kebudayaan Islam 5, no. 1 (9 October 2017), https://doi.org/10.24235/tamaddun.v5i1.1964.

${ }^{21}$ Kuntowijoyo, Budaya Dan Masyarakat (Yogjakarta: Tiara Wacana, 1987); Mastuhu, Dinamika sistem pendidikan pesantren: suatu kajian tentang unsur dan nilai sistem pendidikan pesantren, $2 \mathrm{nd}$ ed. (Jakarta: INIS, 1994).

Tribakti: Jurnal Pemikiran Keislaman

Volume 31, Nomor 2, Juli 2020 


\section{Method}

This study uses qualitative research with a philosophical historical approach. This historical research reveals how KH Munawwar Kholil Gresik during his life made an effort to develop Islamic education in the Gresik and surrounding areas. Sources of data in this research are relic books, papers, documents, and living witnesses who have witnessed KH Munawwar Kholil. ${ }^{22}$ The informants of this research are living witnesses who have seen and witnessed the struggle of Kiai Munawwar Kholil, such as his students, his descendants, his colleagues, and those who had been close to Kiai Munawwar Kholil.

\section{Result and Discussion}

\section{Biography of KH Munawwar Kholil Gresik}

KH Munawwar Adnan Khalil was born in Gresik in 1952 in November 28 after Ashar or in the year of Hijri was born 22 Ramadan $1805 \mathrm{H}$ and died 28 November 2012 in Gresik. His mother was called Nyai Afwah whose message reached Sunan Ampel Raden Rahmatullah namely Afwah bin Mas Amah bint Sayidah Maryam bint Sihhah bin Abdul Jabbar bin Ahmad ibn Pangeran Sambo bin Kyai Joko Tingkir bint Mas Murtasimah bin Sunan Drajat binti Raden Rahmat Sunan Ampel Rahmatullah. While from the Nyai Afwah route it also reaches Sunan Giri Raden Ainul Yaqin. Namely: Nyai Afwah bint Mas Amah bint maryam bint Mbah Brojo until sunan Giri.

As a child before studying at the boarding school, he studied with his father in the village of Suci Manyar Gresik, and Kiai Abdullah Faqih, the founder of the Mambaus Shalihin Gresik cottage (Masbuhin Faqih's father). Studying Fiqh, language, and shorof science to Sheikh Ahmad, Sheikh Amin, and learning Qiraah to Sheikh Abi Dar and Sheikh Ahmad Mursyid and also learning others from his grandfather, Kiai Kholil. ${ }^{23}$

Kiai Munawwar studied at Darul Ubudiyyah Islamic Boarding School Raudhatul Mutaalimin Sawahpoloh Surabaya for Kiai Usman Al-Ishaqi murshid of the Tareeqa Qadiriyah Naqsabandiyah Al-Usmaniyah ${ }^{24}$ for 20 years and at the same time took

${ }^{22}$ A. Daliman, Metode penelitian sejarah (Penerbit Ombak, 2012); John W. Creswell, Qualitative Inquiry \& Research Design: Choosing among Five Approaches, 2nd ed (Thousand Oaks: Sage Publications, 2007).

${ }^{23}$ Kholil Muhammad Munawwar, Badrul Alam, Ala Nahji Al Atam fi Tabwibi Al Hikam (Gresik: PP Daruttaqwa, 2007), End Page. 84.

${ }^{24}$ Van Bruinessen Martin, Tarekat Naqsabandiyah DI Indonesia, 1st ed. (Bandung: Mizan, 1992), 
allegiance to Kiai Usman. Spiritual guide lineage (murshid) Kiai Usman to Rasulallah Saw. When Kiai Usman died and succeeded by his son Kiai Asrori Al-Ishaqi, Kiai Munawwar followed baiat again (tajdid).

During his study at the Islamic boarding school, Kiai Munawwar conducted riyadhah and mujahadah, including 1) not eating rice or anything from rice for 10 years 2) becoming a servant of Kiai ndalem 3) becoming head of a boarding school 4) istiqamah sweeping the Kiai before dawn. 5) write small treatises and share them with friends 6) often don't wear slippers, in java is sandal 7) guardian pilgrimage 9 on foot. Kiai Munawwar during a pilgrimage to the tomb of Sunan Ampel had seen Sunan Ampel come out of his grave and asked for blessings to pray to Sunan Ampel. During Kiai Munawwar's pesantren, he once asked Kiai Usman about his grandfather's Islamic Boarding School, which had no successor. So the answer from Kiai Usman was the responsibility of Kiai Munawwar to develop and revive his grandfather's pesantren again. This biography is in every book written by Kiai Munawwar kholil on the back of the book after the bibliography. ${ }^{25}$

KH Munawwar proved to be very productive in the world of writing and science. This is evidenced by some of his works written in Arabic and Indonesian. His works include: 1) Badrul Alam ala Nahjil Atam fi Tabwibi al Hikam, Syarah Al-Hikamwhich explains Sufism. 2) Roudhatu al Muhibbin ala Nubdati Qalili min Ihyai Ulum ad Diin, 3) Tasfiyatu al Qulub wa tahdibiha, The book explains the cleanliness of the heart (Sufism). 4) Manaqib Auliya Al Falihin (History of the Prophet Muhammad, Companions, and Tabi'in). Series 1 consists of 3 volumes and series 2 consists of 3 volumes. 5) Khoiru Al Zad fi manasik al Hajj, 6) Wadhaif al Rabaniyahabout daily dhikr for students, 7) Khilyatu Al Auliya (History), 8) Qurrata al Aini Fi Manaqibi Al Qutbu Ar Rabbani, 9) Terjemah Nadzam Al-Imrithi (grammatical language), 10) Ajwabu Al Mardhiyah fi Fadhli Mauilidi Khoiru Al-Bariyyah (explains about the history of the birthday (Maulid), and the primacy of the birthday of the Prophet). 11) Nafu Al Amimi Sarhu Minhaj Al Qowimi 4 volumes (sarah Minhajul Qoqim Ibnu Hajar Al-Haitami, explain jurisprudence in a multidisciplinary manner), 12) Faidu Al Ilah Fi Fahdli Dikrillah, explain dzikir thoroughly.

\footnotetext{
${ }^{25}$ Munawwar Kholil Muhammad, Nafu Al Amimi Sarhu Minhaj Al Qowimi (Gresik: Daruttaqwa, 2009).

Tribakti: Jurnal Pemikiran Keislaman Volume 31, Nomor 2, Juli 2020
} 


\section{Contribution in Formal, Non-Formal Education and Life Skills Education}

Looking from the biography of Kiai Munawwar, although he never studied formal education, ${ }^{26}$ he has a passion and a strong willingness to integrate dhikr and thinking so that it is actualized formal education and religious education. Not only religious education but he also established several formal education starting from early childhood to college. From observations and interviews with ${ }^{27}$ as follows:

"Di pondok pesantren Daruttaqwa Gresik ini diresmikan sejak tahun 1989 oleh bupati $H$ Amiseno dan sejak itulah pendidikan di Daruttaqwa berkembang hingga saat ini. Yayasan Al-Munawwar memiliki lembaga dari anak usia dini hingga perguruan tinggi. Tidak hanya pendidikan formal saja pendidikan non formal juga terdapat dalam naungan yayasan seperti Taman Pendidikan Al-Quran TPQ dan Pendidikan Diniah"." [At the Daruttaqwa Gresik Islamic boarding school, it was inaugurated since 1989 by the district head, $\mathrm{H}$ Amiseno, and since then education in Daruttaqwa has continued to this day. Al-Munawwar Foundation has institutions from early childhood to tertiary institutions. Not only formal education, non-formal education also exists in the auspices of foundations such as the TPQ AlQur'an Education Park and Relegious Education"].

The struggle to make boarding schools and the institutions that are in it certainly is not easy and this certainly requires struggle. ${ }^{28}$ Beginning inaugurated by the Regent in 1987 Kiai Munawwar taught his students with classical pesantren education such as mengaji, reading the yellow book (kitab kuning), relegious education and life skill education or the term pesantren culture is called khidmah. Students who came and studied with Kiai Munawwar at that time just a few, and he was very patient in teaching his students even though there were only one or two people. Because he was a devout santri to his teacher, Kiai Munawwar carried out what Kiai Ahmad Asrori Al-Ishaqi had said “ kalau ingin menjadikan pesantren ini maju dan berkembang, maka buatlah lembaga pendidikan formal' ${ }^{29}$

\footnotetext{
${ }^{26}$ Munawwar Kholil Muhammad, Manaqib Auliyą Al Falihin (Gresik: Daruttaqwa, 2010).

${ }^{27}$ Ahmad Taufiq, Wawancara, Alumni Pondok Pesantren Daruttaqwa Gresik, 2020.

${ }^{28}$ Kadariska, 'Perjuangan K.H. Ahmad Sanusi dalam Memajukan Pendidikan Islam di Sukabumi Tahun 1922-1950'; Dewi Rohmawati, 'Perjuangan K.h. Muhammad Sholeh Dalam Mengembangkan Pondok Pesantren Attanwir Talun Sumberrejo- Bojonegoro Tahun 1933-1992', Avatara 3, no. 2 (21 May 2015), https://jurnalmahasiswa.unesa.ac.id/index.php/avatara/article/view/11497; Mujamil Qomar, Pesantren: dari transformasi metodologi menuju demokratisasi institusi (Ciracas, Jakarta: Erlangga, 2005).

${ }^{29}$ Ernawati, 'Kepemimpinan Kh. Munawar Adnan Kholil Dalam Mengembangkan Pondok Pesantren Daruttaqwa Suci Gresik Tahun 1987-2012', 99. 
As a submissive and obedient student to his murshid teacher, Kiai Munawwar began to establish a formal Madrasah Tsanawiyah Daruttaqwa institution in 1994. He was assisted by students and colleagues to find students to want to study and study at the Daruttaqwa Islamic boarding school. The establishment of the formal institution also followed by other institutions such as Madrasah Aliyah Daruttaqwa at the high school level, Madrasah Ibtidaiyah at the Elementary School level, and Roudlatul Athfal at the Kindergarten level. Not satisfied just like that, in 1998 Kiai Munawwar initiated to establish an Islamic high school because it was to accommodate aliyah madrasa graduates who were unable to study outside the pesantren environment. Until the year $2000,{ }^{30}$ the implementation of high schools had been owned by the Daruttaqwa Islamic College of Islamic Education (PAI).

At present Daruttaqwa Islamic Boarding School which was established by Kiai Munawwar Kholil has many educational institutions under the auspices of AlMunawwar Foundation, including 1) Early childhood education 2) Madrasah Ibtidaiyah (MI Daruttaqwa) Elementary School 3) Madrasah Tsanwiyah Daruttaqwa, Junior High School 4) Daruttaqwa Middle School 5) Madrasah Aliyah Daruttaqwa 6) Daruttaqwa High School 7) Daruttaqwa Vocational School. 8) Daruttaqwa Islamic High School (STAI). Besides formal institutions the Daruttaqwa pesantren also has non-formal institutions such as 1) Daruttaqwa TPQ 2) rellgious Madrasah 3) language course institutions. 4) life skills education.

What characterizes Daruttaqwa Islamic boarding school is the life skill education given by Kiai Munawwar to her students. Various kinds of expertise taught by Kiai Munawwar is to establish the independence of students from an early age. This is certainly in line with the objectives of Islamic boarding schools in general that in addition to forming human tafaquh fi $\mathrm{din}^{31}$ but they are also provided with the expertise to face challenges in the community independently. ${ }^{32}$ Like what the Daruttaqwa Pesantren Alumni said that:

\footnotetext{
${ }^{30}$ Surat Keputuan, 'Surat Keputusan Pendirian Sekolah Tinggi Daruttaqwa Gresik', 2000.

${ }^{31}$ Munawar Rahmat, 'Kiai Hasan Ulama Mursyid Tarekat Shaththariah As a Pioneer of Modern Pesantren', Jurnal Pendidikan Islam 7, no. 1 (27 August 2018): 1-22, https://doi.org/10.14421/jpi.2018.71.1-22; Nur Hasan, 'Model Pembelajaran Berbasis Pondok Pesantren Dalam Membentuk Karakter Siswa Di Pondok Pesantren Raoudhotut Tholibin Rembang Jawa Tengah', Wahana Akademika: Jurnal Studi Islam Dan Sosial 3, no. 2 (2016): 72.

${ }^{32}$ Ahmad Kawakib, 'Tujuan Pendidikan Islam', Al-Fitrah 10, no. 1 (2016); Gunt ur Cahaya Kesuma, 'Refleksi Model Pendidikan Pesantren Dan Tantangannya Masa Kini', Tadris: Jurnal Keguruan Dan Ilmu Tribakti: Jurnal Pemikiran Keislaman Volume 31, Nomor 2, Juli 2020
} 
"Kiai Munawwar used to teach his students with khidmah, such as construction work for porters, roan, cattle herding, and so on. This activity is to form students who can face the community in the future. Kiai Mjunawwar Said 'Santri must be able to do everything including trading, working, lecturing, and others. Life in the community does not only discuss nahwu and shorof but various positive activities. And the most important of the khidmah is the blessing and pleasure of Kiai. Because Kiai Munawaar used to study at the Islamic boarding school not only to recite the Koran but was also able to be a servant, a sweeper, a kiai washerwoman and also the head of a boarding school ".

Life skill education taught by Kiai Munawwar does not only fill empty activities in pesantren but is an activity can form students to live independently, mature, and strong in facing life's challenges. Life skill activities such as building workers, sweeping, casting, entrepreneurship, watering, electricity, trading, radio broadcasting, and so on. Cultural life skills activities at Daruttaqwa Islamic Boarding School are referred to as khidmah (helping). The khidmah culture in this pesantren is believed to be a positive value to increase blessing in seeking knowledge in the Islamic Boarding School. So that most students who study at this pesantren have different expertise. This is in line with Agil Siraj ${ }^{33}$ that students do not only learn and obtain a diploma but can submit and obey the Kiai so that they gain wisdom and blessings. ${ }^{34}$

Life skill education in Daruttaqwa Islamic Boarding School is not included in the curriculum but becomes a tradition that doing expertise in Islamic boarding schools is a provision for living in the community. This is certainly an effort in Islamic education, especially pesantren, to reduce the distance between theoretical education and daily life. ${ }^{35}$ The Islamic Boarding School also teaches its students to understand the reality to look at their real lives through the expertise of Kiai Munawwar. This means that Kiai Munawwar's effort teaches a wide range of academic skills and skills to his students for provision in the world and the hereafter. This is in line with the definition

Tarbiyah 2, no. 1 (24 June 2017): 67-79, https://doi.org/10.24042/tadris.v2i1.1740; Agil Sirajl Said, Tasawuf Sebagai Kritik Sosial (Bandung: Mizan, 2006), 216.

${ }^{33}$ Said, Tasawuf, 205.

${ }^{34}$ Seyyed Hossein Nasr, 'The heart_of_islam', n.d., 119; Zainuddin Syarif, 'Mitos Nilai-Nilai Kepatuhan Santri', Tadris: Jurnal Pendidikan Islam 7, no. 1 (2013): 29, http://www.ejournal.stainpamekasan.ac.id/index.php/tadris/article/view/376; Arif Zamhari, Rituals of Islamic Spirituality a Study of Majlis Dhikr Groups in East Java (S.1.: ANU E Press, 2010), 87.

${ }^{35}$ Agus Hasbi Noor, 'Pendidikan Kecakapan Hidup (life Skill) Di Pondok Pesantren Dalam Meningkatkan Kemandirian Santri', Empowerment: Jurnal Ilmiah Program Studi Pendidikan Luar Sekolah 4, no. 1 (28 February 2015): 3-4, https://doi.org/10.22460/empowerment.v4ilp1-31.553. 
of life skills education according to Anwar cited by ${ }^{36}$ that life skills education is to provide practical life provisions and ready-to-use abilities to students.

The following are life skill education taught by Kiai Munawwar Kholil Gresik as follows :

Tabel 1.1 Life Skill Education taught by Kiai Munawwar Kholil Gresik

\begin{tabular}{|c|c|}
\hline $\begin{array}{l}\text { Form of life skill } \\
\text { education }\end{array}$ & Explanation \\
\hline Entrepreneur & $\begin{array}{l}\text { Santri is given full responsibility to manage the canteen well } \\
\text { without leaving other obligations. }\end{array}$ \\
\hline Carpentry & $\begin{array}{l}\text { Santri is equipped with physical endurance and the ability to design } \\
\text { buildings. This expertise that is often paid attention to by Kiai } \\
\text { Munawwar aside from developing pesantren but also making } \\
\text { students more skilled in doing work. }\end{array}$ \\
\hline
\end{tabular}

Radio Announcer, Santri fully manages radio management so that students are able Reporter, Journalism and know governance and ethics of publications and journalism.

Teaching and Santri who have graduated with bachelor degrees have the Learning opportunity to teach in formal institutions.

Animal husbandry Santri is the responsibility of managing cattle and goat farms without forgetting to leave the learning obligation. This is also the same as in the biography of Kiai Munawwar that he once herded goats like the Prophets ${ }^{37}$.

Clinical Management Santri responsibility for managing pesantren clinics and pharmacies. Santri is also appointed to help doctors and midwives. (until Kiai Munawwar once wanted to establish a College of Health $^{38}$

Driver Santri gives the responsibility to manage boarding school travel. Santri is also given full responsibility to manage each vehicle (truck) boarding school.

Plantation

The santri are given insight and knowledge as well as plantation management practices. Pesantren manages mango, vegetable and tuber gardens.

Tailor

Santri gave a chance to improve the economy of pesantren because the uniform is sewn by themselves.

Besides that, there is a unique thing done by Kiai Munawwar to teach students riyadah and mujahadah. Kiai Munawwar always gives a message to his students who do not to buy food outside the boarding school environment. This is certainly not without cause but for the stability of pesantren and reducing the delinquency of students who like to leave boarding schools without permission. In line with ${ }^{39}$ contained in the book

\footnotetext{
${ }^{36}$ Siti Rohmah, 'Manajemen Pengembangan Kecakapan Hidup Untuk Meningkatkan Kemandirian Santri Di Pesantren', TADBIR MUWAHHID 1, no. 2 (30 October 2017): 179, https://doi.org/10.30997/jtm.v1i2.1093.

${ }^{37}$ Muhammad Munawwar, Badrul Alam, Biografi.

${ }^{38}$ Ernawati, 'Kepemimpinan Kh. Munawar Adnan Kholil Dalam Mengembangkan Pondok Pesantren Daruttaqwa Suci Gresik Tahun 1987-2012', 99.

${ }^{39}$ Burhanul Islam Al-Zarnuji, Tălimul Mutaalim (Surabaya: Al-Hidayah, n.d.), 14.
}

Tribakti: Jurnal Pemikiran Keislaman

Volume 31, Nomor 2, Juli 2020 
of talimul mutaaliim that a person in learning conditions must reduce food from the market and avoid unclean things.

The special characteristic of education carried out by Kiai Munawwar is tawassuth (not too figh and not too Sufism). Although he is a Sufi follower of the tareqa Qadiriyya Naqsabandiyya who is devout, in daily life and how to educate always use the middle way. Kiai Munawwar prefers someone who does worship regularly and istiqamah. In fact, on various occasions, he often advised his students that "a person who is Sufism is not surprised or easily amazed by things in the world". ${ }^{40}$ The statement above actually shows that God is making things so that as obedient servants, events in the world are a sign of His sorrow.

\section{Educational Objectives}

In general, Kiai Munawwar has educational goals often mentioned on various occasions, namely 1) make an ulama and 2) be a generous tycoon. This was told by one of his students "Studying in this Islamic Boarding School be a Kiai or Ulama and be a rich and generous person". ${ }^{41}$ The educational goals initiated by Kiai Munawwar are indeed not specific, but already covered in a ukhrowi and worldly manner. In line with ${ }^{42}$ that Islamic education includes religious goals (Gardhu diny) and worldly goals (gardu dunya). The educational objectives of most Islamic boarding schools are mostly by his personality and his background in learning. ${ }^{43}$

Kiai Munawwar has implemented the objectives of pesantren education as having the following characteristics: 1) Morals are more important than mere knowledge but not moral. 2) Santri demanding knowledge-seeking blessings of teachers is the main goal when the blessing is obtained even if only a little it will make the world happy and the hereafter 3) students must be able to do anything (flexible). 4) don't forget about history, meaning a student must know his origins.

\footnotetext{
${ }^{40}$ Lesmana, Wawancara: Alumni Pondok Pesantren Daruttaqwa, 2020.

${ }^{41}$ Lesmana.

${ }^{42} \mathrm{H}$. M Arifin, Ilmu pendidikan Islam: suatu tinjauan teoritis dan praktis berdasarkan pendekatan interdisipliner (Jakarta: Bumi Aksara, 2006).

${ }^{43}$ Mohammad Muchlis Solichin, 'Pendidikan Islam Moderat Dalam Bingkai Kearifan Lokal', Jurnal Mudarrisuna: Media Kajian Pendidikan Agama Islam 8, no. 1 (20 July 2018): 174-94, https://doi.org/10.22373/jm.v8i1.2950. 


\section{Writing Many Books as Identity and Pioneer The Kiai}

Kiai Munawwar with his preoccupation as ulama and often received invitations from the public, he was also very fond of writing the book of Jurisprudence, Sufism, History of Prophet, and so on. This is not without reason, but the results of interviews with his assistant (abdi ndalem) during his lifetime. According to the audience:

"Kiai Munawwar was so fond and happy with the world of education. He wrote several phenomenal works such as the book of Fiqh, Sufism, and Islamic history. He wrote when he was approaching dawn around 3 o'clock. Before writing, he prayed the night before and continued writing with various references. His references are the books of mutabarah which he possesses such as Tafsir Kabir, jam ul jawami, Musnad Ahmad, and so on. So many books. His love by writing and reading books he showed by carrying books wherever and wherever. In the car, there is always a book brought by him". ${ }^{44}$

From the explanation above, it is exemplary that a Kiai who is busy with teaching and khadimul ummah activities still loves to write and read books of muatabarah. Not many met a Kiai with his preoccupation with the Ummah but still able to write ${ }^{45}$ which are very monumental. What makes Kiai Munawwar unique is that his works are all Arabic. According to Bruinessen the tendency of modern scholars to write more in Indonesian. ${ }^{46}$ Although he was clever and created several works that many Kiai Munawwar still offered, this is evidenced by his work that had received the blessing and the foreword from KH Maimun Zubair praised KH Munawar as the Tasawuf Ulama. ${ }^{47}$

Writing skills and patience in serving the community seem to make a Kiai preferred and trusted by the community. ${ }^{48}$ Many people also flock to ask for advice, prayers, blessings, and send their children to the boarding school. Such a role is carried out by the Kiai so that ordinary people have a reference in religion. ${ }^{49}$

\footnotetext{
${ }^{44}$ Andik Firmansyah, Wawancara, Kepala Pondok Pesantren Daruttaqwa Tahun 2020, 2020.

${ }^{45}$ Abdul Malik Karim Amrullah, 'Perubahan Dan Perkembangan Model Pesantren', El-Hikmah 0, no. 0 (27 April 2013), http://ejournal.uin-malang.ac.id/index.php/elhikmah/article/view/2238.

${ }^{46}$ Van Bruinessen Martin, Kutab Kuning Pesantren dan Tarekat, 1st ed. (Yogyakarta: Gading Publising, 2012), 78.

${ }^{47}$ Muhammad Munawwar, Badrul Alam.

${ }^{48}$ Ahmad Faris, 'Kepemimpinan Kiai Dalam Mengembangkan Pendidikan Pesantren', 'Anil Islam: Jurnal Kebudayaan Dan Ilmu Keislaman 8, no. 1 (30 June 2015): 123-44, http://jurnal.instika.ac.id/index.php/AnilIslam/article/view/39; Wawan Arwani, 'Kiai Pesantren Dan Kontribusinya Dalam Mengembangkan Pluralitas Keberagamaan Dan Toleransi Di Kabupaten Cirebon', Holistik 15, no. 1 (5 April 2016), https://doi.org/10.24235/holistik.v15i1.434.

${ }^{49}$ Amrullah, 'Kontribusi Karya Tulis Kiai Basori Alwi Terhadap Pengembangan Wawasan Keagamaan Masyarakat', 41.
} 
The book written by Kiai Munawwar studied by Daruttaqwa students. Bandongan and wetonan agreements carried out at the Islamic Boarding School alternately by his sons, along with senior Ustadz who had received a mandate from Kiai Munawwar. According to the author, there is a phenomenal book from Kiai Munawwar is the book of Naful Amim which consists of 4 volumes and in every volume consists of 600 pages. The Book of Naful Amim gave guidance to the book of Minhajul Qowim by Ibn Hajar Al-Haitami and reviewed fiqh in various perspectives from history, fiqh of four mazhab of thought, fiqh contradictions, and contextual fiqh. ${ }^{50}$ Although it has been written into four volumes, this work has not yet been completed perfectly because Kiai Munawwar was called by Allah on November 28, 2012.

The books written by Kiai Munawwar show that the world of pesantren is dynamics. In the pesantren curriculum, Kiai Munawwar's works are included in learning. Kiai's writings show that he has his identity and expertise so that it becomes a reference for ordinary people. ${ }^{51}$ Kiai Munawwar besides being called a patient Kiai, he also received praise from several Kiai in East Java and Central Java as Kiai who was good at writing books even though he had never been educated in the Arabian peninsula (only learning on pesantren which taught by KH Usman Al-Ishaqi Sawahpuluh Surabaya during 20 Years). ${ }^{52}$

One of Kiai Munawwar's works formed by his background and daily life is Faidu Al Ilah. Most of the Kiai or Ulama works are influenced by his educational and daily background..$^{53}$ This book explores the importance of the dhikr which is reviewed and refers to several mutabarah books such as Tafsir Kabir, Tafsir Al-Qurtubi, Kutub As Sitah, Tarikh Al Baghdad.History of dimisqoq and the monumental book of other classical scholars. ${ }^{54}$

Kiai Munawar's daily life is teaching santri, attending remembrance assemblies (Majlis Dhikr), attending invitations from various communities, supervising santri in developing skills, and various other positive activities. Every day it is only aimed at

\footnotetext{
${ }^{50}$ Muhammad, Nafu Al Amimi Sarhu Minhaj Al Qowimi.

${ }^{51}$ Amrullah, 'Kontribusi Karya Tulis Kiai Basori Alwi Terhadap Pengembangan Wawasan Keagamaan Masyarakat'.

${ }^{52}$ Kieswono, 'Biografi Kh. M. Munawwar Adnan Kholil Ponpes Daruttaqwa Suci Gresik', Biografi Kh. M. Munawwar Adnan Kholil Haul Akbar Ponpes Daruttaqwa Suci Gresik (blog), accessed 24 February 2020, http://haulakbar.blogspot.com/2018/02/biografi-kh-m-munawwar-adnan-kholil.html.

${ }^{53}$ Wildan Wiratdoni, 'Analisis Konsep Penciptaan Seni Lukis Kaligrafi Islami Karya Ahmad Mustofa Bisri', 2018.

${ }^{54}$ Kholil Muhammad Munawwar, Faidul Ilah fi Fadli Dizkri Allah (Gresik: PP Daruttaqwa, 2011). 
positive activities by seeking the blessings of Allah. As has been stated in the recording of recitation and written in the Book of Faid Al Ilah about dhikr that is "All positive activities such as trading, teaching, farming, and others are partially intended by Allah so they are referred to as remembrance". ${ }^{55}$

\section{Educating with Storytelling Method (Qissoh)}

Storytelling is one of the methods of educating, ${ }^{56}$ in character education storytelling is also one of the strategies to internalize values and become a bridge of communication between students and parents and the community. ${ }^{57}$ Storytelling is an educational method that famous, this is proven by the way Kiai Munawwar does in lecturing and educating students. This is in line with what was explained by Husnur Rofiq Alumni Daruttaqwa Islamic Boarding School that:

"Kiai Munawwar is an expert in storytelling. On various occasions when teaching and lecturing the content and delivery of meaning given many uses the stories of a wali, motivational stories, and exemplary stories that exist in the past. I often remember when I was studying at Daruttaqwa Islamic Boarding School was Shodin's story. Shodin is a santri who is not handsome or even looks unsightly, but he is a person who is active in learning, memorizing Alfiah for only one week. The true story is that Shodin was a santri who got blessings from his Kiai because he was earnest in learning ".

The story presented by Kiai Munawwar is in a humorous and relaxed way. So, many people who listen are very enthusiastic. Expert in telling the history of Islam is not only in explaining when reciting and lecturing but Kiai Munawwar showed by writing the Book of Al-Auliya 'Al Falihin which consists of 2 editions. Each edition consists of three volumes and each volume consists of 600 to 700 pages. The contents of this book are the stories of the Prophet, the Prophet Sabahat, tabiin, and tabiit. ${ }^{58}$

Kiai Munawwar has similarities with several other Kiai in developing Islamic education, namely in applying his writing as curriculum material in recitation. This method was also carried out by Kiai Asrori, and kiai Bashori Alwi Malang. This

\footnotetext{
${ }^{55}$ Munawwar Kholil Muhammad, Pengajian Faid Al-Ilah, MP3 (Gresik, 2009).

${ }^{56}$ Aat Hidayat, 'Rekonstruksi Pendidikan Islam Dalam Perubahan Mindset Masyarakat Gunung Kemukus', Edukasia: Jurnal Penelitian Pendidikan Islam 13, no. 2 (11 February 2018), https://doi.org/10.21043/edukasia.v13i2.3636.

${ }^{57}$ Thomas William Nielsen, 'Towards a Pedagogy of Imagination: A Phenomenological Case Study of Holistic Education', Ethnography and Education 1, no. 2 (2006): 247-264; Muzdalifah M. Rahman, Metode Bercerita Membentuk Kepribadian Muslim Pada Anak Usia Dini (ThufuLa, 2013).

${ }^{58}$ Muhammad, Manaqib Auliya Al Falihin.
}

Tribakti: Jurnal Pemikiran Keislaman

Volume 31, Nomor 2, Juli 2020 
similarity is likely because the three Kiai were both studying with Kiai Usman Al-Ishaqi Surabaya. Another similarity is that some Kiai love the world of written works. Each Kiai has its own expertise as does Kiai bashori alwi Malang who is an expert in the field of qiraat, Kiai Asrori Al-Ishaqi is an expert in the fields of Sufism and tarekat while Kiai munawaar Khalil is an expert in the field of history and Sufism, which means the methods of education delivered are also different.

\section{Conclussion}

Kiai Munawwar made a huge contribution to the world of Islamic education, especially in Gresik. This can be seen from the institutions under the Al-Munawwar Foundation, which consists of early childhood education to tertiary education. It is not only an institution but also a way of educating students who have become a tradition in the pesantren environment, namely life skill education (khidmah). Besides that, Kiai Munawwar Adnan Kholil Gresik also contributed by writing books from Arabic. Kiai Munawwar's writings are also part of the education curriculum at the Daruttaqwa Islamic Boarding School. His writings show that the capacity of a kiai and his head in the field of religion so that it becomes a reference for the community. Kiai Munawwar's works also inspire people in general and the students, who are qualified human beings, are the ones who leave written works.

Thanks to: The whole family of Kiai Munawwar, Nyai Nur Qomariyah Setyawati Wulandari, Kiai Kholil Tanthowi, Kiai Ainul Muttaqien, Nyai Nur Silva Nabila, Nyai Nur Maftuhatun Nadiah, Kiai Fadlullah Nabhan.

\section{References}

Ahmad Taufiq. Wawancara, Alumni Pondok Pesantren Daruttaqwa Gresik, 2020.

Al-Zarnuji, Burhanul Islam. Ta limul Muta `alim. Surabaya: Al-Hidayah, n.d.

Amanda, Charisma. “"Religi” Sebagai Pendekatan Desain Untuk Fasilitas Wisata Di Kota Gresik'. Jurnal Sains Dan Seni ITS 4, no. 2 (2016).

Amrullah, Abdul Malik Karim. 'Kontribusi Karya Tulis Kiai Basori Alwi Terhadap Pengembangan Wawasan Keagamaan Masyarakat'. Ulul Albab Jurnal Studi Islam 13, no. 1 (17 September 2013): 35-48. https://doi.org/10.18860/ua.v0i0.2381.

'Perubahan Dan Perkembangan Model Pesantren'. El-Hikmah 0, no. 0 (27 April 2013). http://ejournal.uin-malang.ac.id/index.php/elhikmah/article/view/2238. 
Andik Firmansyah. Wawancara, Kepala Pondok Pesantren Daruttaqwa Tahun 2020, 2020.

Arifin, H. M. Ilmu pendidikan Islam: suatu tinjauan teoritis dan praktis berdasarkan pendekatan interdisipliner. Jakarta: Bumi Aksara, 2006.

Arwani, Wawan. 'Kiai Pesantren Dan Kontribusinya Dalam Mengembangkan Pluralitas Keberagamaan Dan Toleransi Di Kabupaten Cirebon'. Holistik 15, no. 1 (5 April 2016). https://doi.org/10.24235/holistik.v15i1.434.

As'ad, Mahrus. 'Tajdīd Al-Tarbīyah al-Islāmīyah 'inda al-Shaykh al-Ḥājj Imam Zarkasyi'. Studia Islamika 22, no. 2 (31 August 2015): 333-68. https://doi.org/10.15408/sdi.v22i2.1922.

Chairudin, Mochamad. 'Strategi Pengembangan Pondok Pesantren Qomaruddin Gresik' . Jurnal Ilmu Pendidikan Islam 15, no. 1 (16 June 2017): 73-88. http://ejournal.kopertais4.or.id/pantura/index.php/jipi/article/view/3378.

Chotimah, Chusnul. 'Pendidikan Kewirausahaan Di Pondok Pesantren Sidogiri Pasuruan'. Inferensi: Jurnal Penelitian Sosial Keagamaan 8, no. 1 (2014): 114-36. https://doi.org/10.18326/infs13.v8i1.114-136.

'Counter_webgresik', 2016. https://www.powr.io/hit-counter/u/f0c2dd77_1501400614.

Creswell, John W. Qualitative Inquiry \& Research Design: Choosing among Five Approaches. 2nd ed. Thousand Oaks: Sage Publications, 2007.

Daliman, A. Metode penelitian sejarah. Penerbit Ombak, 2012.

Dhofier, Zamakhsyari. Tradisi pesantren: studi pandangan hidup kyai dan visinya mengenai masa depan Indonesia. Cet. 8 rev. Jakarta: LP3ES, 2011.

Ernawati. 'Kepemimpinan Kh. Munawar Adnan Kholil Dalam Mengembangkan Pondok Pesantren Daruttaqwa Suci Gresik Tahun 1987-2012'. Avatara 3, no. 2 (21 May 2015). https://jurnalmahasiswa.unesa.ac.id/index.php/avatara/article/view/11496.

Faridatin, Nora. 'Kota Gresik Sebagai Kota Santri "Implikasi Sebagai City Branding"”. Thaqafiyyat: Jurnal Bahasa, Peradaban Dan Informasi Islam 17, no. 1 (2 June 2016): 106-21. http://202.0.92.5/adab/thaqafiyyat/article/view/1083.

Faris, Ahmad. 'Kepemimpinan Kiai Dalam Mengembangkan Pendidikan Pesantren'. 'Anil Islam: Jurnal Kebudayaan Dan Ilmu Keislaman 8, no. 1 (30 June 2015): 12344. http://jurnal.instika.ac.id/index.php/AnilIslam/article/view/39.

Hasan, Nur. 'Model Pembelajaran Berbasis Pondok Pesantren Dalam Membentuk Karakter Siswa Di Pondok Pesantren Raoudhotut Tholibin Rembang Jawa Tengah'. Wahana Akademika: Jurnal Studi Islam Dan Sosial 3, no. 2 (2016): 92-110.

Hidayat, Aat. 'Rekonstruksi Pendidikan Islam Dalam Perubahan Mindset Masyarakat Gunung Kemukus'. Edukasia: Jurnal Penelitian Pendidikan Islam 13, no. 2 (11 February 2018). https://doi.org/10.21043/edukasia.v13i2.3636.

Kadariska, Siti. 'Perjuangan K.H. Ahmad Sanusi dalam Memajukan Pendidikan Islam di Sukabumi Tahun 1922-1950’. Diploma, UIN Sunan Gunung Djati Bandung, 2018. http://digilib.uinsgd.ac.id/13700/.

Kawakib, Ahmad. 'Tujuan Pendidikan Islam'. Al-Fitrah 10, no. 1 (2016).

Tribakti: Jurnal Pemikiran Keislaman

Volume 31, Nomor 2, Juli 2020 
Kesuma, Guntur Cahaya. 'Refleksi Model Pendidikan Pesantren Dan Tantangannya Masa Kini'. Tadris: Jurnal Keguruan Dan Ilmu Tarbiyah 2, no. 1 (24 June 2017): 67-79. https://doi.org/10.24042/tadris.v2i1.1740.

Kieswono. 'Biografi Kh. M. Munawwar Adnan Kholil |Ponpes Daruttaqwa Suci Gresik'. Biografi Kh. M. Munawwar Adnan Kholil| Haul Akbar Ponpes Daruttaqwa Suci $\begin{array}{lllll}\text { Gresik (blog). } \quad \text { Accessed } 24 & \text { February }\end{array}$ http://haulakbar.blogspot.com/2018/02/biografi-kh-m-munawwar-adnankholil.html.

Kompasiana. 'Julukan Gresik Kota Santri'. Kompasiana, 2018. https://www.kompasiana.com/hana5301/5d8a391f0d823073b6406072/julukangresik-kota-santri.

Kuntowijoyo. Budaya Dan Masyarakat. Yogjakarta: Tiara Wacana, 1987.

Lesmana. Wawancara: Alumni Pondok Pesantren Daruttaqwa, 2020.

Ma`arif, Muhammad Anas, and Muhammad Husnur Rofiq. 'Dzikir Dan Fikir Sebagai Konsep Pendidikan Karakter: Telaah Pemikiran KH. Munawwar Kholil Al-Jawi'. Tadrib 5, no. 1 (1 July 2019): 1-20. https://doi.org/10.19109/tadrib.v5i1.3066.

Martin, Van Bruinessen. Kutab Kuning Pesantren dan Tarekat. 1st ed. Yogyakarta: Gading Publising, 2012.

Tarekat Naqsabandiyah DI Indonesia. 1st ed. Bandung: Mizan, 1992.

Mastuhu. Dinamika sistem pendidikan pesantren: suatu kajian tentang unsur dan nilai sistem pendidikan pesantren. 2nd ed. Jakarta: INIS, 1994.

Muhammad Munawwar, Kholil. Badrul Alam, Ala Nahji Al Atam fi Tabwibi Al Hikam. Gresik: PP Daruttaqwa, 2007.

—. Faidul Ilah fi Fadli Dizkri Allah. Gresik: PP Daruttaqwa, 2011.

Muhammad, Munawwar Kholil. Manaqib Auliya`Al Falihin. Gresik: Daruttaqwa, 2010.

—. Naf u Al Amimi Sarhu Minhaj Al Qowimi. Gresik: Daruttaqwa, 2009.

—. Pengajian Faid Al-Ilah. MP3. Gresik, 2009.

Nasir, M. Ridlwan, and M. Adib Abdushomad. Mencari Tipologi Format Pendidikan Ideal: Pondok Pesantren Di Tengah Arus Perubahan. Cet. 1. Yogyakarta: Pustaka Pelajar, 2005.

Nasr, Seyyed Hossein. 'The_heart_of_islam', n.d., 227.

Nielsen, Thomas William. 'Towards a Pedagogy of Imagination: A Phenomenological Case Study of Holistic Education'. Ethnography and Education 1, no. 2 (2006): 247264.

Noor, Agus Hasbi. 'Pendidikan Kecakapan Hidup (life Skill) Di Pondok Pesantren Dalam Meningkatkan Kemandirian Santri'. Empowerment: Jurnal Ilmiah Program Studi Pendidikan Luar Sekolah 4, no. 1 (28 February 2015): 1-31. https://doi.org/10.22460/empowerment.v4i1p1-31.553. 
Qomar, Mujamil. Pesantren: dari transformasi metodologi menuju demokratisasi institusi. Ciracas, Jakarta: Erlangga, 2005.

Rahman, Muzdalifah M. Metode Bercerita Membentuk Kepribadian Muslim Pada Anak Usia Dini. ThufuLa, 2013.

Rahmat, Munawar. 'Kiai Hasan Ulama Mursyid Tarekat Shaththariah As a Pioneer of Modern Pesantren'. Jurnal Pendidikan Islam 7, no. 1 (27 August 2018): 1-22. https://doi.org/10.14421/jpi.2018.71.1-22.

Ramayulis. Sejarah Pendidikan Islam, Napaktilas Perubahan Konsep, Filsafat dan Metodelogi Pendidikan Islam dari Era Nabi Saw sampai Ulama`Nusantara. Jakarta: Kalam Mulia, 2012.

Riyadi, Abdul Kadir. 'The Concept of Man in Ahmad Asrori's Anthropology of Tasawuf'. Journal of Indonesian Islam 11, no. 1 (9 July 2017): 223-246-246. https://doi.org/10.15642/JIIS.2017.11.1.223-246.

Rohmah, Siti. 'Manajemen Pengembangan Kecakapan Hidup Untuk Meningkatkan Kemandirian Santri Di Pesantren'. TADBIR MUWAHHID 1, no. 2 (30 October 2017): 177-82. https://doi.org/10.30997/jtm.v1i2.1093.

Rohmawati, Dewi. 'Perjuangan K.h. Muhammad Sholeh Dalam Mengembangkan Pondok Pesantren Attanwir Talun Sumberrejo- Bojonegoro Tahun 1933- 1992'. Avatara 3, no. 2 (21 https://jurnalmahasiswa.unesa.ac.id/index.php/avatara/article/view/11497.

Said, Agil Sirajl. Tasawuf Sebagai Kritik Sosial. Bandung: Mizan, 2006.

Sayono, Joko. 'Perkembangan Pesantren Di Jawa Timur'. Bahasa Dan Seni, 2005.

Solichin, Mohammad Muchlis. 'Pendidikan Islam Moderat Dalam Bingkai Kearifan Lokal'. Jurnal Mudarrisuna: Media Kajian Pendidikan Agama Islam 8, no. 1 (20 July 2018): 174-94. https://doi.org/10.22373/jm.v8i1.2950.

Sunyoto, Agus. Atlas Wali Songo: buku pertama yang mengungkap Wali Songo sebagai fakta sejarah. Kerjasama Pustaka IIMaN, Trans Pustaka, dan LTN PBNU, 2016.

Surat Keputuan. 'Surat Keputusan Pendirian Sekolah Tinggi Daruttaqwa Gresik', 2000.

Syafaah, Aah. 'Menelusuri Jejak Dan Kiprah Kiai Kholil Al-Bangkalani'. Jurnal Tamaddun: Jurnal Sejarah Dan Kebudayaan Islam 5, no. 1 (9 October 2017). https://doi.org/10.24235/tamaddun.v5i1.1964.

_ . 'Peran Dan Perjuangan Kiai Masykur Di Desa Karangsari Weru Cirebon (18351961)'. Holistik 1, no. 2 (1 December 2016): 215-27. https://doi.org/10.24235/holistik.v1i2.1124.

Syarif, Zainuddin. 'Mitos Nilai-Nilai Kepatuhan Santri'. Tadris: Jurnal Pendidikan Islam 7, no. 11 (2013): 19-30. http://www.ejournal.stainpamekasan.ac.id/index.php/tadris/article/view/376.

Takdir, Mohammad. 'Kontribusi Kiai Kholil Bangkalan Dalam Mengembangkan Tasawuf Nusantara'. 'Anil Islam: Jurnal Kebudayaan Dan Ilmu Keislaman 9, no. 2 (31 December 2016): 268-99. http://jurnal.instika.ac.id/index.php/AnilIslam/article/view/18. 
Wasid, and Mahsun. 'Kiai Abdul Hamid Pasuruan Dan Kontribusinya Untuk Moderasi Islam'. Al Fikrah 1, no. 1 (2018): 71-81.

Wiratdoni, Wildan. 'Analisis Konsep Penciptaan Seni Lukis Kaligrafi Islami Karya Ahmad Mustofa Bisri’, 2018.

Zamhari, Arif. Rituals of Islamic Spirituality a Study of Majlis Dhikr Groups in East Java. S.1.: ANU E Press, 2010.

Zarkasyi, Hamid Fahmy. 'Appraising the Moderation Indonesian Muslims with Special Reference to Muhammadiyah and Nahdlatul Ulama'. Addin 12, no. 1 (2018): 1-30. https://www.neliti.com/publications/272038/appraising-the-moderation-indonesianmuslims-with-special-reference-to-muhammadi. 